\title{
ИНТЕЛЕКТУАЛНИ КАПИТАЛ КАО СТРАТЕШКА ПРЕДНОСТ ПРЕДУЗЕКА
}

\author{
Марко Шпилер ${ }^{1}$ Стефан Милојевић², Милорад Ковјанић³
}

Резиме: Интелектуални капитал представља ресурс од кључног значаја за стварање економског богатства. 3бог значаја који интелектуални капитал има у данашњем високо конкурентном и динамичном окружењу, о њему се говори са различитих аспеката. Циљ рада је да укаже на значај који интелектуални капитал данас има у унапређењу перформанси са освртом на медије. У истраживању је коришћена метода анализе садржаја.

Кључне речи: људски ресурси, интелектуални капитал, предузеће, стратешка предност, медији

\section{УВОД}

Иако је постојао експлозиван интерес када је у питању интелектуални капитал и жеђ за информацијама о томе како би се њиме могло управљати, мало је тога написано да би се описао или дефинисао сам концепт (Edvinsson \& Sullivan, 1996). Термин „интелектуални капитал“ John Kenneth Galbraith први је објавио, а његово гледиште је да ће интелектуални капитал вероватно бити динамичан, а не статички облик капитала.

У економији заснованој на знању, интелектуални капитал је од највеће важности. Примена интелектуалног капитала је од суштинског значаја за опстанак организације у конкурентској индустрији као што су медији (Wang et al., 2014).

Материјална имовина, као што су некретнине, постројења и опрема и даље представљају важан фактор у производњи добара и услуга. Међутим, њихов релативни значај се временом смањивао, с једне стране, док се значај нематеријалне имовине засноване на знању, повећавао, с друге стране

Универзитет у Београду, Факултет организационих наука, e-mail: mspiler@gmail.com

2 АЛФА БК Универзитет, Факултет за финансије, банкарство и ревизију у Београду, e-mail:aviation.adviser@gmail.com

3 ГО Земун, e-mail: kovjanicmilorad64@gmail.com 
(Luthy, 1998). Другим речима, у економијама заснованим на знању, интелектуални капитал представља примарни ресурс у стварању вредности (Chenetal., 2005). Даље, услед тих промена, разматрана су критична рачуноводствена питања за управљање имовином, као што су називи брендова, пословне тајне, производни процеси, канали дистрибуције и компетенције у вези са радом.

Tornburg (1994) наглашава вредност мерења интелектуалног капитала за развој људских ресурса. Он истиче да је тек када се развију смислене мере, обезбеђен предуслов да се мери ефикасност програма дизајнираних да повећају капацитет интелектуалног капитала.

Многе фирме су почеле да откривају информације о интелектуалном капиталу. Финансијски аналитичари, међутим, траже више информација у вези са стратегијом и често сматрају да су извештаји о интелектуалном капиталу мање релевантни (Bukh, 2002).

У раду је указано на важност адекватног управљања људским ресурсима, а потом је дат осврт на интелектуални капитал као стратешку предност предузећа и осврт на његову улогу у медијима. Кроз закључна разматрања су предложени могући правци будућих истраживања, а након тога је приказана литература.

\section{Управљање људским ресурсима у савременом предузећу}

Како наводе Дмитровић и др. (2018) у стратегији данашњих компанија долази до промена у смислу померања са конкурентског позиционирања индустријске структуре ка пословним процесима и интерним факторима (различите обуке и знање запослених, пословна култура, нове вештине учења, организациона клима, административне способности, репутација и др). Интелектуални капитал и друштвени капитал имају значајан утицај на иновације (Salehietal, 2021).

Управљање људским ресурсима бави се изазовима са којима се суочавају менаџери људских ресурса, интегришући традиционалну теорију са стратегијом у стварном свету знања, ради стицања вештина које су им потребне да напредују у глобалном пословању које се стално мења (Stewart \& Brown, 2020).

Људски ресурси фирме могу се дефинисати као колективне способности запослених да реше проблеме купца (Edvinsson \& Sullivan, 1996). Постоји много аутора који су се бавили проблематиком управљања људским ресурсима. Менаџмент људских ресурса је тај који координира регрутовање, обуку и развој кадрова за све аспекте организације (Ghillyer, 2018; Ognjanović, 2020).

Друштвени медији постају витални елемент интензивног раста интелектуалног капитала. Њихов крајњи облик одређују динамичне техничке ино- 
вације (укључујући хибридне производе и услуге), активности мерџера и аквизиција међу иноваторима производа и услуга, као и понашање корисника (који отеловљују саму друштвену димензију ових медија) (Wiśniewski, 2013).

Репортери су витални људски капитал у новинским организацијама. Поред тога што креирају и дистрибуирају вести као извор знања, представљају и друштвени капитал јер морају да развију односе са изворима вести изван организације. Међутим, тешко је искористити и задржати интелектуални капитал. Новинска организација губи и људски и друштвени капитал кад год извештач да отказ или се запосли (Wang et al., 2014).

\section{Интелектуални капитал и медији}

Традиционално се богатство сматрало физичким и финансијским ресурсом. Међутим, током протеклих неколико деценијама та вредносна једначина је драстично промењена. Највреднија имовина сваког друштва је његово знање - ресурс са много већом вредношћу од било ког другог, материјалних добара или финансијских удела. Постоји много дефиниција интелектуалног капитала. Интелектуални капитал је широко дефинисан као знање, интелектуална својина или искуство које се може користити у генерисању богатства (Garcia-Meca \& Martınez, 2005). Претпоставља нематеријалну природу, што га разликује од ресурса традиционално препознатих у корпоративним финансијским извештајима. Једна од њих је да је интелектуални капитал „знање које има вредност за организацију” (Akpinar \& Akdemir, 1999). Stewart (1997) дефинише интелектуални капитал као интелектуални материјал (као што су знање, информације, интелектуална својина и искуство) који се може користити за стварање богатства. Његови главни елементи су људски капитал, структурни капитал и релациони капитал. Људски капитал је онај који је састављен од вредности, ставова и навика компоненти организације (Sánchez \& Cañizaresetal, 2007). Управо ова дефиниција сугерише да управљање знањем (збир онога што је познато) ствара интелектуални капитал (Sánchez \& Cañizaresetal., 2007). Реч је о облику интелектуалног капитала који није у власништву предузећа, већ у власништу запослених (Modal \& Ghosh, 2012). Структурни капитал укључује процесе, пословне моделе, методологију управљања, док се релациони капитал односи на базу корисника, односе с корисницима и односе са осталим стејкхолдерима (Радоњић, 2021). Истиче да релациони и структурни капитал позитивно утичу на конкурентску предност, те да они чине 48,4\% конкурентске предности. Ова два облика интелектуалног капитала, за разлику од људског капитала, у власништву су предузећа.

Неочекивано је открити да људски капитал нема значајан директан утицај на конкурентску предност. Међутим, ваљано је констатовати да 
људски капитал индиректно и значајно утиче на конкурентску предност јер је уграђен у релациони капитал (Yaseen et al., 2018).

У доба економије засноване на знању и након опсежних друштвеноекономских промена, успех организација није ограничен на стицање финансијскихиматеријалних ресурса.Реалностањеједауспешност профитно оријентисаних организација у првој мери зависи од стицања нематеријалне имовине која се може користити за постизање одрживе конкурентске предности (Wang, 2021). У новом стратешком окружењу, организације ће напредовати када себе виде као организацију која учи, а чији је циљ да континуирано унапређује интелектуални капитал; организација која не може да повећа свој интелектуални капитал не може да опстане.

За реализацију циљева, неопходни су одговарајући ресурси. Ресурси укључују сва финансијска, физичка, људска, нематеријална и структурална средства која организација користи за развој, производњу и испоруку производа или услуга купцима (Симоновић и др., 2019). Нематеријална имовина се може посматрати као покретач финансијских перформанси, посебно у ИТ индустрији (Radonjić et al., 2021) и према њеном утицају на ефикасност компаније (Radonjić et al., 2020).

Приказ 1: Типови нематеријалне имовине, EVLIA метод

\begin{tabular}{|c|c|c|c|}
\hline Људски ресурси & $\begin{array}{c}\text { Интелектуална } \\
\text { својина }\end{array}$ & $\begin{array}{c}\text { Организациони } \\
\text { капитал }\end{array}$ & $\begin{array}{c}\text { Релациони } \\
\text { капитал }\end{array}$ \\
\hline $\begin{array}{l}\text { Предузетничко } \\
\text { рачуноводство }\end{array}$ & $\begin{array}{c}\text { Кодификовано } \\
\text { знање } \\
\text { Базе података, } \\
\text { процедруе и } \\
\text { приручници }\end{array}$ & $\begin{array}{c}\text { Методе/процедуре } \\
\text { за производњу/ } \\
\text { набавку услуга }\end{array}$ & $\begin{array}{c}\text { Привлачење } \\
\text { купаца }\end{array}$ \\
\hline $\begin{array}{c}\text { Едукација особља и } \\
\text { компетенције }\end{array}$ & $\begin{array}{c}\text { Пословне информа- } \\
\text { ције Трговинске и } \\
\text { пословне тајне }\end{array}$ & Сертификација & $\begin{array}{c}\text { Управљање } \\
\text { портфолијом } \\
\text { купаца }\end{array}$ \\
\hline $\begin{array}{c}\text { Know how и } \\
\text { тацитно знање }\end{array}$ & Патенти и изуми & $\begin{array}{c}\text { Алати и системи } \\
\text { пројектног } \\
\text { менаџмента }\end{array}$ & $\begin{array}{c}\text { Управљање } \\
\text { добављачима }\end{array}$ \\
\hline \multirow[t]{3}{*}{$\begin{array}{c}\text { Мотивација особља } \\
\text { и лојалност }\end{array}$} & $\begin{array}{c}\text { Робне марке и } \\
\text { брендови }\end{array}$ & $\begin{array}{c}\text { Административни } \\
\text { систем }\end{array}$ & $\begin{array}{l}\text { Кооперација и } \\
\text { умрежавање }\end{array}$ \\
\hline & Дизајн и модели & & \\
\hline & Ауторска права & & \\
\hline
\end{tabular}

Извор: EVLIA method for the identification and description of competitively relevant intangible assets, www.evlia.eu, преузето из: Кнежевић, С. (2019), Финансијско извештавање, издање аутора, Београд 
Интелектуални капитал представља велику вредност за профитно оријентисане организације у данашње време (Ковјанић \& Вукадиновић, 2021). Посао менаџера је да знање учини продуктивним,да се интелектуални капитал претвори у вредност „сustomer value“. Интелектуални капитал се не односи само на податке или информације у фајловима и базе података. Он садржи сво корисно знање у било ком облику у организацији.

Колективни аргументи користи друштвених медија у стварању интелектуалног капитала су видљиви, међутим, остаје питање да ли је то добар извор за покретање одрживе експанзије интелектуалног капитала (Falkowski, 2014).

Потребно је нагласити чињеницу да је интелектуални капитал једина значајна имовина фирме. Како истиче Marr (2005), за разлику од њега, већина осталих средстава (зграда, фабрика, опрема, машине и др.) почињу да се амортизују након стављања у употребу. Поред тога, битно питање је и разматрање права интелектуалне својине, што представља веома сложену проблематику (Radovanović et al., 2016).

\section{ЗАКЉУЧАК}

Истраживања приказана у раду имала су за циљ да сагледају веому важну улогу коју у данашњем, високо конкурентом окружењу има интелектуални капитал. Све је већа свест о томе да је интелектуални капитал кључна имовина за успех у данашњем привредном окружењу. Да би предузеће напредовало, интелектуални капитал мора да расте. Ефикасно управљање интелектуалним капиталом почиње разумевањем. Из тог разлога, овај рад је дао дефиницију интелектуалног капитала како би помогао менаџерима да разумеју ширину захтева менаџмента.

Компаније које данас послују морају да обезбеде услове да обелодањују информације о њиховим кључним изворима богатства заинтересованим странама (разним интересним групама), а они су све више оријентисани ка нематеријални типовима ресурса компаније.

Управљање интелектуалним капиталом је у повоју, али интересовање расте у континуитету. У новије време су уложени значајни напори да се развију ефикасни модели за мерење интелектуалног капитала уз ентузијастично експериментисање. У сваком случају, индиција је да свака организација треба да почне своју потрагу за разумевањем и стручношћу у управљању еминентним средством за стварање богатства у будућности у турбулентном окружењу, а то је интелектуални капитал. 


\section{ЛИТЕРАТУРА}

1. Akpinar, A.T. \& Akdemir, A. (1999). Intellectual capital.In: Third European Conference, 332-340.

2. Bukh, P. N. (2002). The relevance of intellectual capital disclosure: a paradox? Accounting, Auditing \& Accountability Journal, 16(1): 49-56. https://doi. org/10.1108/09513570310464273

3. Chen, C.M., Cheng, S.J., \& Hwang, Y. (2005). An empirical investigation of the relationship between intellectual capital and firms' market value and financial performance. Journal of Intellectual Capital, 6(2): 159-176.

4. Dmitrović, V., Simeunović, B., \& Knežević, S. (2018). Establishinga system for intellectual capital measuring and reporting. Hawai'i Accounting Research Conference - HARC 2018, University of Hawaii ' at Mānoa, Honolulu, Hawaii, Zbornik radova (Elektronsko izdanje), 03-05. 01. 2018., 1-13 http://hdl.handle.net/10125/51983

5. Edvinsson, L. \& Sullivan, P. (1996). Developing a model for managing intellectual capital. European Management Journal, 14(4): 356-364. https://doi.org/10.1016/02632373(96)00022-9

6. Falkowski, M. (2014). Social media's role in intellectual capital's growth. Review of Business and Economics Studies, 2(2): 66-74.

7. Garcia-Meca, E. \& Martıez, I. (2005). Assessing the quality of disclosure on intangibles in the Spanish capital market. European Business Review, 17(4): 305-13.

8. Ghillyer, A.W. (2018). Business ethics now, (5 $5^{\text {th }}$ edition), McGraw-Hill Education, New York.

9. Inkinen, H., Kianto, A., Vanhala, M., \& Ritala, P. (2017). Structure of intellectual capital - an international comparison. Accounting, Auditing and Accountability Journal, 30(5): 1160-1183. https://doi.org/10.1108/AAAJ-11-2015-2291

10. Knežević, S., \& Mitrović, A. (2015). The accounting treatment of internally generated intangible assets. Cracow University of Economics, Cracow 2015, Managementof entrepreneurship in a knowledge-based economythe issue of knowledgeand intellectualcapital management, Scientific editors: Marek Makowiec, Tomasz Kusio, Department of Organizational Behaviour, Cracow University of Economics, 97-107.

11. Кнежевић, С. (2019). Финансијско извештавање. Издање аутора. Београд.

12. Ковјанић, М. \& Вукадиновић, П. (2021). Интелектуални капитал као стратешка перформанса банке са освртом на банке. Банкарство, 50(1): 90-107 https://doi. org/10.5937/bankarstvo2101090K 
13. Luthy, D.H. (1998). Intellectual Capital and Its Measurement. New Forms of Accounting and Auditing, College of Business Utah State University.

14. Marr, B. (2005). Perspectives on Intellectual Capital. Elsevier Butterworth-Heinemann.

15. Mondal, A., \& Ghosh, S. K. (2012). Intellectual capital and financial performance of Indian banks. Journal of Intellectual Capital, 13(4): 515-530. https://doi. org/10.1108/14691931211276115

16. Ognjanović, J. (2020). Employer brand and workforce performance in hotel companies. Hotel and Tourism Management, 8(2): 65-78. https://doi.org/10.5937/menhottur20020650

17. Radovanović, N., Dmitrović, V., \& Knežević, S. (2016). Protection of intellectual property rights: what do financial reports say? XV International symposium „Reshaping the Future Through Sustainable Business Development and Entrepreneurship SymOrg 2016", June 10-13, Zlatibor, Faculty of organizational sciences, Belgrade.

18. Radonić, M., Knežević, S., Mitrović, A., \& Milojević, S. (2020). How does the intangible asset affect company efficiency? Evidence from the listed companies in Serbia's meat industry. Custos e Agronegócio Online, 16(4): 51-78.

19. Radonić, M., Milosavljević, M., \& Knežević, S. (2021). Intangible Assets as Financial Performance Drivers of IT Industry: Evidence from an Emerging Market. E\&M Economics and Management, 24(2): 119-135. http://dx.doi.org/10.15240/tul/001/2021-2-008

20. Радонић, М. (2021). Утицај нематеријалне имовине на вредност компанија у условима глобалне дигитализације. У: Кнежевић, С. (Уред.) Форензичко рачуноводство, истражне радње, људски фактор и примењени алати, 263-289. Београд: Факултет организационих наука.

21. Salehi, M., Ali Fahimi, M., Zimon, G. \& Homayoun, S. (2021). The effect of knowledge management on intellectual capital, social capital, and firm innovation. Journal of Facilities Management. https://doi.org/10.1108/JFM-06-2021-0064

22. Sánchez \& Cañizares, S.M., Ángel Ayuso Muñoz, M. \& López \& Guzmán, T. (2007). Organizational culture and intellectual capital: a new model. Journal of Intellectual Capital, 8(3): 409-430. https://doi.org/10.1108/1469193071077849

23. Stewart, T.A. (1997). Intellectual capital.The new wealth of organisations. Doubleday

24. Stewart, G.L. \& Brown, K.G. (2020).Human resource management: Linking strategy to practice,John Wiley \& Sons.

25. Thornburg, L. (1994). Accounting for knowledge. HR Magazine, October.

26. Wang, C. H, Yen, C. D., Liu, G. H.W. (2015). How intellectual capital influences individual performance: A multi-level perspective. Computers in Human Behavior, 5(2015): 930 937. https://dx.doi.org/10.1016/j.chb.2014.10.044 
27. Wang, P. (2021). A study on the intellectual capital management over cloud computing using analytic hierarchy process and partial least squares. Kybernetes. https://doi. org/10.1108/K-03-2021-0241

28. Wiśniewski, P. (2013). Intellectual Capital (IC) in Social Media Companies: Its Positive and Negative Outcomes. In book: Proceedings of 5th European Conference on Intellectual Capital.Academic Conferences International.

29. Yaseen, Saad G., Dajani, D., \& Hasan, Y. (2016). The impact of intellectual capital on the competitive advantage: Applied study in Jordanian telecommunication companies. Computers in Human Behavior, 62: 168-175. https://doi.org/10.1016/j.chb.2016.03.075 